\title{
Erratum to: A Pilot Study on Neopterin Levels and Tryptophan Degradation in Zinc-Exposed Galvanization Workers
}

\author{
Elif Seyda Sarac • Gözde Girgin • S. Sezin Palabiyik • \\ Mohammad Charehsaz • Ahmet Aydin • Gönül Sahin • \\ Terken Baydar
}

Published online: 8 February 2014

(C) Springer Science+Business Media New York 2014

Erratum to: Biol Trace Elem Res (2013) 151:330-334
DOI: 10.1007/s12011-012-9569-4

The authors have found typing mistakes in Abstract and Table 1. All other data and statistics have been re-checked and confirmed. The necessary corrections are as follows:

\begin{abstract}
Section:
In the sentence "Serum and urinary zinc levels were found as $14.90 \pm 0.90$ and $102 \pm 4.7 \mu \mathrm{g} / \mathrm{dL}$ in workers while $12.87 \pm 1.45$ and $75 \pm 4.2 \mu \mathrm{g} / \mathrm{dL}$ in controls, respectively (both, $\mathrm{p}<0.05$ )."
\end{abstract}

- $\quad 14.90 \pm 0.90$ should be replaced with $102.43 \pm 4.74$

- $102 \pm 4.7$ should be replaced with $0.66 \pm 0.05$

- $\quad 12.87 \pm 1.45$ should be replaced with $75.45 \pm 4.24$

- $75 \pm 4.2$ should be replaced with $0.80 \pm 0.08$

\section{Table 1, last 2 rows:}

- $\quad 12.87 \pm 1.45$ should be replaced with $75.45 \pm 4.24$

- $14.90 \pm 0.90$ should be replaced with $102.43 \pm 4.74$

- $0.80 \pm 0.37$ should be replaced with $0.80 \pm 0.08$

- $0.66 \pm 0.39$ should be replaced with $0.66 \pm 0.05$

The online version of the original article can be found under doi:10.1007/ s12011-012-9569-4.

\section{E. S. Sarac}

Nanotechnology and Nanomedicine Division, Institute of Science,

University of Hacettepe, Beytepe Campus, Ankara, Turkey

G. Girgin · S. S. Palabiyik • G. Sahin · T. Baydar

Department of Toxicology, Faculty of Pharmacy, University of

Hacettepe, Sihhiye Campus, 90-06100 Ankara, Turkey

M. Charehsaz • A. Aydin

Department of Toxicology, Faculty of Pharmacy, University of

Yeditepe, Istanbul, Turkey

G. Sahin

Department of Toxicology, Faculty of Pharmacy, University of

Eastern Mediterranean, Famagusta, TR, North Cyprus

\section{T. Baydar $(\bowtie)$}

Nanotoxicology Group in Nanotechnology and Nanomedicine,

Division, Institute of Science, University of Hacettepe, Beytepe

Campus, Ankara, Turkey

e-mail: tbaydar@hacettepe.edu.tr 